\begin{tabular}{|c|c|c|}
\hline $\begin{array}{l}\text { KULTURA } \\
\text { I } \\
\text { SPOLECZENS }\end{array}$ & $\begin{array}{l}\text { POLSKA AKADEMIA NAUK } \\
\text { KOMITET SOCJOLOGII } \\
\text { INSTYTUT STUDIÓW POLITYCZNYCH } \\
2015, \mathrm{nr} 4\end{array}$ & ISSN 0023-5172 \\
\hline
\end{tabular}

F A K T Y, P R O B L E M Y,

O M Ó W I E N I A

ANTONI Z. KAMIŃSKI

Instytut Studiów Politycznych PAN

BARTŁOMIEJ KAMIŃSKI

Wyższa Szkoła Informatyki i Zarządzania w Rzeszowie

University of Maryland, College Park

\title{
SIŁY MOTORYCZNE ROZWOJU SPOŁECZNO-GOSPODARCZEGO: REFLEKSJE NA KANWIE KONCEPCJI ACEMOGLU-ROBINSONA
}

Wydana w 2012 roku w Stanach Zjednoczonych książka Darona Acemoglu i Jamesa A. Robinsona Dlaczego narody przegrywają: źródła władzy, pomyślności $i$ ubóstwa (wyd. pol. Acemoglu, Robinson 201411) zdobyła sobie natychmiastową popularność. Złożyły się na to dwa czynniki. Po pierwsze, książka ta pojawiła się we właściwych okolicznościach historycznych. Po drugie, jej tematyka mieści się $\mathrm{w}$ dwu kluczowych dla nauk społecznych nurtach: $\mathrm{z}$ jednej strony dotyczy problemu źródeł bogactwa i nędzy narodów, który po raz pierwszy w takim wymiarze podją Adam Smith w słynnym traktacie Badania nad natura $i$ przyczynami bogactwa narodów; $z$ drugiej strony bada przyczyny, które spowodowały, że w XVIII wieku, jak to ujął David S. Landes (2000, s. 223), „świat zerwał się z kotwicy”.

Książka ukazała się w momencie, w którym świat zachodni i cywilizacja ludzka znalazły się na swoistym rozdrożu. Wydarzenia polityczne, a także gospodarcze, lat 2008-2015 położyły kres optymizmowi ostatniej dekady XX wieku oraz pierwszych lat nowego stulecia. Rok 2008 przyniósł koniec boomu gospodarczego oraz odmowę administracji nowo wybranego prezydenta Stanów Zjednoczonych w kwestii kontynuacji aktywnej polityki zagranicznej. Wyjście z kryzysu w Stanach okazało się powolniejsze niż przy poprzednich załamaniach koniunktury, a w Europie wiele krajów doświadczyło nawrotu recesji gospodarczej. Niektórzy ekonomiści zaczęli nawet mówić o zagrożeniu długookresową, sekularną stagnacją gospodarki światowej (Teulings, Baldwin

Adres do korespondencji: kaminski@isppan.waw.pl; bkaminsk@umd.edu

${ }^{1}$ Dalej powołując się to wydanie podajemy w tekście numer strony. 
2014). Abdykacja Ameryki z roli światowego przywódcy wytworzyła próżnię, z której skorzystała Rosja, podważając suwerenność Ukrainy, oraz Państwo Muzułmańskie na Bliskim Wschodzie i Północy Afryki, Chiny zaś zaostrzyły żądania terytorialne pod adresem krajów sąsiednich. W tych nowych warunkach geopolityczno-ekonomicznych pytania, co zrobić, aby odzyskać dynamizm gospodarczy i stabilność polityczną, a także zapobiec konfliktowi światowemu w skali globalnej, są szczególnie na czasie.

Problemy podjęte przez Acemoglu i Robinsona nie są we współczesnych naukach społecznych całkiem zaniedbane. Badania nad czynnikami sprawiającymi, że jedne narody rozwijają się i bogaca, a inne popadają w ubóstwo, podejmowało wielu wybitnych ekonomistów i historyków gospodarczych ${ }^{2}$. Kwestią przyczyn wkroczenia przez Europę Zachodnią na drogę szybkiej modernizacji między wiekiem XVI a XVIII zajęli się socjologowie i historycy sięgający do związanej z nazwiskiem Maksa Webera tradycji badań historyczno-porównawczych ${ }^{3}$. Jeżeli dodać do tego, że Acemoglu i Robinson są profesorami prestiżowych uczelni Bostonu - MIT oraz Harvardu - o znaczącym dorobku naukowym, to książka, w której podjęto tak zasadnicze kwestie w czasie, gdy opinię publiczną dręczy niepokój związany z zagrożeniami gospodarczymi i politycznymi, musiała trafić na listę bestsellerów „New York Timesa”, zbierając wyrazy uznania ze strony pięciu, reprezentujących odmienne orientacje polityczne, laureatów Nagrody Nobla oraz grona wybitnych ekonomistów i historyków gospodarczych.

Ta zgodność opinii przedstawicieli szerokiego spektrum politycznego jest szczególnie warta podkreślenia z uwagi na to, że Acemoglu-Robinson stają w obronie liberalnego kapitalizmu: a ten, choć wygrał $z$ komunizmem i zapewnił największy wzrost dobrobytu w historii ludzkości, nigdy nie cieszył się uznaniem elit intelektualnych krajów, które najwięcej mają mu do zawdzięczenia 4 . Terminu „kapitalizm” wprawdzie nie można znaleźć w indeksie książki, ale zdaniem laureata Nagrody Nobla z 2001, George Ackerloffa ${ }^{5}$ — odpowiedź na pytanie o czynniki przesądzające o sukcesie lub porażce kraju we wspinaniu się po drabinie dobrobytu daje ona na miarę Badań nad natura i przyczynami

\footnotetext{
2 Np. Carlo Cipolla (1970), Mancur Olson (1982), Charles E. Kindleberger (1996), Douglas C. North (1981, 1990); David S. Landes (2000), Ian Bremmer (2006), Paul Collier (2007). Rozwoju struktur politycznych zaś dotyczy ogromnie znacząca praca Samuela Huntingtona (1968).

${ }^{3}$ Np. Karl Wittfogel (1956), Barrington Moore, Jr. (1966), Charles Tilly (1990, 1997), Immanuel Wallerstein (1974); Theda Skocpol (1979), Harold Berman (1995).

${ }^{4} \mathrm{Nie}$ jest to zjawisko nowe. Ludwig von Mises poświęcił awersji intelektualistów do kapitalizmu szereg szkiców, napisanych przed ponad pół wiekiem, zebranych w książce The Anti-Capitalistic Mentality opublikowanej przez the Ludwig von Mises Institute w Auburn (2008); książka jest dostępna elektroniczne (http://mises.org/library/anti-capitalistic-mentality).

${ }^{5}$ Ackerloff porównuje książkę Acemoglu i Robinsona do dzieła Smitha podkreślając, iż podjęli oni podobną problematykę na porównywalną skalę. Według niego, za dwieście lat nasi potomkowie będą czytać Dlaczego narody przegrywaja, podobnie jak my nadal czytamy Adama Smitha. Zobacz okładkę wydania amerykańskiego Crown Business (2014).
} 
bogactwa narodów Adama Smitha. Istotnie, tak Adam Smith, jak Acemoglu i Robinson siły motoryczne rozwoju społeczno-gospodarczego widzą w demokracji $\mathrm{i}$ instytucjach wspierających konkurencję między autonomicznymi aktorami.

W odróżnieniu od Adama Smitha, który polemizując z ekonomią merkantylizmu przedstawił złożoną, o silnym ładunku normatywnym, koncepcję alternatywnego systemu społeczno-gospodarczego, Acemoglu i Robinson poświęcają więcej uwagi zmianom $\mathrm{w}$ instytucjach politycznych i ich wpływowi na procesy zachodzące $\mathrm{w}$ gospodarce. W szczególności podkreślają rolę tych instytucji w pośredniczeniu między grupami społecznymi i rozwiązywaniu sprzeczności interesów, co wpływa zwrotnie na na ich ewolucję. Bogaty materiał historyczny rozpatrują na gruncie zaproponowanej przez siebie konceptualizacji systemów polityczno-gospodarczych, o czym poniżej. Na podstawie analizy historycznej ewolucji konkretnych przypadków próbują ustalić czynniki sprawcze klęski lub sukcesu, wskazując na rolę przypadku $\mathrm{w}$ pojawianiu się krytycznych zakrętów historii (critical junctures) oraz na adaptację do wyzwań stwarzanych przez zewnętrzne układy polityczno-gospodarcze.

Autorzy za punkt wyjścia przyjęli prosty, dychotomiczny podział instytucji na wyłączające (extractive ${ }^{6}$ ) i włączające (inclusive). Podstawowa różnica między nimi to łatwość wejścia i swoboda uczestniczenia w życiu politycznym i gospodarczym. Pierwsze zapewniają panowanie nad społeczeństwem wąskiej grupie lub koalicji grup, które zawłaszczają, poprzez instytucje polityczne i gospodarcze, narzędzia przymusu oraz wartości materialne i ideowe, wyłączając większość społeczeństwa z udziału w nich. Drugie - mają charakter otwarty, dopuszczają do formalnego uczestnictwa we władzy i podziale dóbr materialnych większość lub całość społeczeństwa, nie wykluczając zarazem z góry żadnej grupy. Kluczowa teza, jaka wynika z prezentowanych w książce analiz, brzmi: instytucje włączające sprzyjają innowacji i rozwojowi gospodarki, podczas gdy instytucje wyłączające - uniemożliwiając innowacyjność — hamują rozwój.

Autorzy rozpatrują oddzielnie sferę instytucji politycznych i gospodarczych. W rezultacie otrzymujemy cztery możliwe konfiguracje (zob. tabela 1). Dwie są „czystymi kombinacjami”, czyli zakładają pełną zgodność instytucjonalną między sferą polityki i gospodarki. Na podstawie analizy historycznej autorzy pokazują, że kombinacja instytucji wyłączających (kwadrant 1) nie generuje rozwoju, podczas gdy warunki w sposób względnie trwały sprzyjające innowacji i wzrostowi dobrobytu towarzyszyły tylko kombinacji instytucji włączających (kwadrant 4).

Pozostałe dwie kombinacje, w których instytucjom wyłączającym w jednej sferze towarzyszą instytucje włączające w drugiej, zawierają sprzeczność wewnętrzną między dwiema różnymi logikami funkcjonowania porządku spo-

${ }^{6}$ Choć tłumaczenie terminów w polskim wydaniu książki jest poprawne, to w języku angielskim termin extractive ma znacznie bogatsze konotacje niż „wyłączające” w języku polskim. Sugeruje bowiem nie tylko ekskluzywność, ale również wyzysk za sprawą niedopuszczania konkurencji. 
łecznego. Włączające instytucje polityczne mają na dłuższą metę nikle szanse przetrwania, kiedy system ekonomiczny oparty jest na wyłączności (kwadrant 3) ${ }^{7}$. W sytuacji odwrotnej, współistnienia wyłączającego systemu politycznego i włączającej gospodarki, przetrwanie zależy od warunków historycznych i jakości elity władzy, lecz w dłuższym okresie może generować trudne do opanowania $\mathrm{w}$ ramach takiego układu instytucji napięcia polityczne $\mathrm{i}$ gospodarcze (kwadrant 2) ${ }^{8}$.

Tabela 1

Dynamika zmian przy różnych kombinacjach typów instytucji gospodarczych i politycznych

\begin{tabular}{|c|c|c|}
\hline \multirow[b]{3}{*}{ 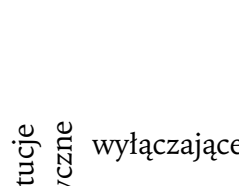 } & \multicolumn{2}{|c|}{ Instytucje gospodarcze } \\
\hline & wyłączające & włączające \\
\hline & $\begin{array}{l}\text { (1) błędne koło (,spirala występku”- } \\
\text { stagnacja) }\end{array}$ & $\begin{array}{l}\text { (2) czasowo stabilna kombinacja: cen- } \\
\text { tralizacja polityczna i rynek }\end{array}$ \\
\hline 占 & (3) niestabilna kombinacja & $\begin{array}{l}\text { (4) „spirala cnoty” (samonapędzający } \\
\text { się rozwóju dzięki innowacji) }\end{array}$ \\
\hline
\end{tabular}

Sukces gospodarczy krajów o wyłączających ustrojach politycznym i włączających rozwiązaniach ekonomicznych w pewnym stopniu podważa tezę, że demokracja jest warunkiem koniecznym i wystarczającym dołączenia danego kraju do grupy najwyżej rozwiniętych. Prowokuje też do zadania pytania o możliwość utrzymania dynamiki wzrostu w miarę zbliżania się do poziomu krajów wysoko rozwiniętych. Autorzy nie pozostawiają tych pytań bez odpowiedzi. Co do pierwszej kwestii wskazują, na przykładzie państw Azji Wschodniej, na centralizację władzy politycznej i sprawną biurokrację jako kluczowe składniki sukcesu. Należy jednak pamiętać, że państwa te prowadziły świadomą politykę włączania się do gospodarki globalnej. Ten strategiczny wybór zdeterminował prowadzoną przez nie politykę gospodarczą.

Wyłączające instytucje polityczne same w sobie nie stanowią bariery wzrostu, gdy o wzroście gospodarczym decydują nie innowacje, ale przede wszystkim mobilizacja ekstensywnych czynników wzrostu. Sukces zależy wtedy jedynie od umiejętności kopiowania technologii stworzonych w krajach wysoko rozwiniętych, a nie od zdolności innowacyjnych. Te ostatnie nabierają znaczenia w miarę jak kraj zbliża się do, jak to określa terminologia ekonomiczna,

\footnotetext{
7 Koncentracja instrumentów władzy ekonomicznej na ogół jest nie do pogodzenia $z$ otwartym włączającym systemem politycznym. Ale są oczywiście wyjątki. Przykładem współwystępowania instytucji włączających w polityce $z$ instytucjami wyłączającymi w gospodarce jest ustrój Rzeczypospolitej Polski i Litwy w wiekach XV i XVI.

8 Dyskutowany w pracy przykład odmiennych trajektorii rozwoju podzielonej Korei jest, z jednej strony, dobrą ilustracją tezy o wpływie instytucji; z drugiej — pokazuje, iż w warunkach kombinacji politycznych instytucji wyłączających i ekonomicznych instytucji włączających wzrost gospodarczy jest możliwy.
} 
światowej granicy technologicznej. Oznacza to, że po osiągnięciu pewnego poziomu rozwoju gospodarki jej dalszy rozwój zależy od stworzenia warunków do technologicznej innowacji. Niemniej jednak nawet w warunkach dominacji wyłączania w sferze politycznej dominacja instytucji włączających w gospodarce wymusza na tej pierwszej pewien stopień otwarcia na zewnętrzne interesy czyli włączenia.

Acemoglu i Robinson dopuszczają zatem stopniowalność cech wykluczania lub włączania przez istniejące systemy instytucjonalne. Podkreślają, że wyeliminowanie instytucji wyłączających i zastąpienie ich instytucjami włączającym w sferze gospodarki wymaga silnej, scentralizowanej i zdeterminowanej władzy politycznej. W każdych warunkach jest ona czynnikiem niezbędnym, by zapewnić wzrost gospodarczy. Koronnym przykładem jest tu spektakularny wzrost gospodarki chińskiej. W Chinach, a później w Indiach, niezbędna do uruchomienia procesów wzrostu była reforma biurokratycznych mikrozarządzanych gospodarek narodowych. W obydwu krajach barierę wzrostu gospodarczego stanowiło przeciążenie regulacyjne i ingerencja państwa ad hoc w bieżące zarządzanie. Istotę przejścia od centralnego planowania do gospodarki rynkowej stanowiła likwidacja tych struktur i zastąpienie ich rozwiązaniami „prorozwojowymi”. Ale czy było to też doświadczeniem innych krajów, które także zmniejszyły dystans dzielący je od krajów wysoko rozwiniętych?

Odpowiedź na to pytanie wymaga odniesienia do innych krajów, które odnotowały sukces gospodarczy. Do grupy tej na pewno można zaliczyć te, które określa się często, od tytułu raportu Banku Światowego (BS 1993) im poświęconego, jako kraje „cudu wschodnioazjatyckiego”. Raport omawia źródła sukcesu ośmiu krajów Azji Wschodniej: Japonii, Hong Kongu, Korei Południowej, Singapuru, Taiwanu oraz Indonezji, Malezji i Tajlandii. Ponieważ od publikacji tego raportu upłynęło blisko ćwierć wieku i ograniczył się on do jednego regionu świata, należy też wziąć pod uwagę wyniki ostatnich lat. Czyni to w sposób elegancki raport Komisji Wzrostu (KW 2008), w którym poddano analizie podobieństwa i różnice między krajami spektakularnego wzrostu. Za kryterium oceny uznano osiągnięcie stopy wzrostu PKB (produkt krajowy brutto) większej lub równej siedmiu procentom przez co najmniej dwadzieścia lat, w okresie 1950-2005. Są to wysokie wymagania: przy stopie wzrostu siedmiu procent podwojenie dochodu narodowego następuje co dziesięć lat ${ }^{9}$. Jedynie trzynaście krajów może się poszczycić tym, że PKB spełnia powyższe warunki. Poza wspomnianymi ośmioma krajami „cudu wschodnioazjatyckiego” są to Botswana, Brazylia, Chiny, Malta i Oman (KW 2008, s. 19-20) ${ }^{10}$. Kraje te są bardzo różnorodne pod względem wyposażenia w bogactwa naturalne, liczby

\footnotetext{
${ }^{9}$ Kraje spełniające te warunki stanowiły przedmiot analizy Komisji Wzrostu (jej członkami byli zarówno wybitni politycy, jak i ekonomiści).

10 Gdyby rozszerzyć analizę do lat 2005-2014, to w grupie tej znalazłyby się przypuszczalnie Indie i Wietnam.
} 
ludności, położenia geograficznego, klimatu oraz instytucji polityczno-gospodarczych. Co łączyło więc kraje spektakularnego sukcesu?

Na pytanie to autorzy raportu Komisji Wzrostu dają następującą odpowiedź. Łączy je pięć cech: wszystkie (1) wykorzystały możliwości stwarzane przez integrację globalną; (2) utrzymały stabilność makroekonomiczną; (3) miały wysokie stopy oszczędzania i inwestowania; (4) pozwoliły mechanizmowi rynkowemu na alokację zasobów; (5) stworzyły sprawną i wiarygodną administrację. Cechy te, z wyjątkiem ostatniej, zależą od decyzji z zakresu polityki gospodarczej. Bez sprawnego i kompetentnego rządu konsekwentna realizacja polityki nie byłaby możliwa (KW 2008, s. 21).

Tezę Acemoglu-Robinsona o niezbędności instytucji włączających, zarówno ekonomicznych, jak i politycznych, dla utrzymania wzrostu na najwyższym poziomie rozwoju przez długi okres potwierdza - jak się wydaje - fakt, iż wszystkie kraje, które dołączyły do grupy najwyżej rozwiniętych państw świata, a tym samym znalazły się na granicy krzywej światowych możliwości technologicznych, mają włączające instytucje polityczne oraz gospodarcze. Z wyjątkiem Hong Kongu, który nie jest niezależnym państwem, pozostałe bogate kraje z tej grupy - Japonia, Korea Południowa, Malta, Singapur i Taiwan - są demokracjami opartymi na konkurencyjnych rynkach.

Czynnikiem komplikującym, choć zarazem wzbogacającym analizę dynamiki, jest uwzględnienie współwystępowania instytucji włączających z wyłączającymi w obrębie domeny politycznej lub ekonomicznej. Przejście od dominacji jednego typu instytucji do drugiego może być pobudzane przez czynniki wewnętrzne lub zewnętrzne - jedna $z$ tych możliwości nie wyklucza drugiej. Najczystszym, błyskotliwie opisanym w książce Acemoglu-Robinsona, historycznym przypadkiem endogeniczności czynników ewolucji wzmacniających ewolucję $\mathrm{w}$ kierunku przewagi instytucji włączających są zmiany zachodzące w ustroju politycznym Anglii od Magna Carta z 1215 roku przez Chwalebną Rewolucję lat 1688-1689 aż do zniesienia ustaw zbożowych w 1846 roku. $\mathrm{W}$ tym stopniowym ruchu w kierunku dominacji instytucji włączających było wiele przypadkowości, a wyniki kolejnych zmian nie były z góry przesądzone.

Może też jednak wystąpić endogenicznie pobudzana ewolucja w stronę przeciwną - od instytucji włączających w kierunku przewagi instytucji wyłączających. Obecnie zarówno w Europie Zachodniej, jak i w Stanach Zjednoczonych można dostrzec symptomy instytucjonalnego „zamykania się”, przejawiające się $\mathrm{W}$ ograniczeniu konkurencji przez na przykład regulacje podnoszące koszt wejścia, rozpoczęcia działalności gospodarczej, czy nakładanie warunków formalnych, na przykład dopuszczenia do zamówień publicznych (np. Bessen 2015). 
Edmund Phelps (2013) swą niedawno wydaną książkę poświęcił załamaniu się dynamiki innowacyjności w wyniku ograniczeń spowodowanych dominacją interesów kolektywistycznych (czytaj: instytucji wyłączających), zmniejszeniem swobody działalności gospodarczej. Statystyki wyraźnie wskazują na słabnięcie ducha przedsiębiorczości w Stanach Zjednoczonych, spowodowane wzrostem stopnia „zamkniętości” różnych sfer działalności politycznej i gospodarczej. Spadek udziału nowych firm o wysokiej technologii tłumaczy się rosnącymi kosztami wejścia, które chronią firmy już istniejące: korupcja ochrony patentów oraz zmiana systemu zamówień wojskowych, czyli ograniczenie do już istniejących, dużych przedsiębiorstw z długą historią tych zamówień (zob. Bessen 2015; Chambers, Ullman 2015).

O ile ewolucja instytucjonalna w Anglii w znacznej mierze była endogeniczna, o tyle w innych krajach okazała się $z$ reguły reakcją na wyzwania zewnętrzne, która mogła iść w różnych kierunkach. Acemoglu-Robinson w rewolucji francuskiej widzą reakcję na rosnącą potęgę Wielkiej Brytanii, a w otwarciu się Japonii na świat zewnętrzny - dążenie do utrzymania suwerenności wobec wyzwań stwarzanych przez industrializację i ekspansję Europy i Ameryki Północnej. Z kolei dziewiętnastowieczne Chiny zareagowały na te wyzwania odmiennie - przez zamknięcie się. Najbardziej płodne pola dla badań znajdują się $z$ jednej strony na kontinuum między dwoma typami instytucji, a $z$ drugiej - w układach charakteryzujących się współwystępowaniem obu typów instytucji, włączających i wyłączających, zarówno w polityce, jak i w sferze gospodarki.

Jak wspomniano, Acemoglu i Robinson dopuszczają możliwość zmiany cech układu instytucjonalnego, to jest przejścia od instytucji włączających do wyłączających - i odwrotnie. Zdarza się to wtedy, kiedy społeczeństwa znajdą się w punktach zwrotnych, które umożliwiają zmiany instytucjonalne. O tym, w jakim kierunku one pójdą, często decydują drobne i pozornie mało istotne czynniki. Takie punkty zwrotne wystąpiły parokrotnie w historii Europy, ostatecznie wywołując przyjęcie przez instytucje polityczno-gospodarcze w tej części świata cech włączających. Pozwoliło to uwolnić zawarty w społeczeństwach tego obszaru potencjał rozwoju. Przyjęcie w punkcie zwrotnym instytucji włączających nie oznacza, że proces nie ulegnie odwróceniu, albowiem „drobne różnice instytucjonalne, które odgrywają zasadniczą rolę w punktach zwrotnych, są ze swej natury nietrwałe”. Dlatego łatwo jest zmienić kierunek ewolucji (s. 180). Wskazują też jednak na występowanie sytuacji, w których przewaga określonego typu instytucji uruchamia proces ich samowzmocnienia. Jeśli jest to samowzmacnianie się instytucji wyłączających, to mamy do czynienia z utrwalaniem się status quo ${ }^{11}$. Samowzmacnianie się instytucji włączających prowadzi

${ }^{11} \mathrm{Na}$ temat podobnych analiz samowzmacniających procesów zmiany instytucjonalnej pisali Robert Putnam (1995, s. 276-283) oraz Antoni Z. Kamiński i Bartłomiej Kamiński (2004, s. 265$-267)$. 
do „spirali cnoty”, to jest samonapędzającego rozwoju gospodarczego, który pociąga za sobą otwieranie się instytucji politycznych.

Trzon tendencji inercyjnych wiąże się z interesem klas uprzywilejowanych. Im bardziej otwarty, włączający jest system polityczny, tym większy pluralizm interesów, tym łatwiejsza jest innowacja, także w sferze instytucji politycznych. Rozwój, wszelka innowacja, polega na „twórczej destrukcji”, czyli zastępowaniu jednych rozwiązań technologicznych lub organizacyjnych przez inne, bardziej sprawne. Warunkiem dopuszczenia do zmiany, przy przewadze instytucji wyłączających w układzie politycznym, jest utrzymanie kontroli nad procesem społecznym: zmiana jest dopuszczalna tylko w takim stopniu, $\mathrm{w}$ jakim nie zagraża monopolowi kontroli nad cenionymi zasobami. Sugeruje to, że w procesie rozwoju gospodarczego instytucje polityczne grają rolę dominującą, co autorzy explicite stwierdzają pisząc: „[...] wprawdzie instytucje gospodarcze decydują o biedzie lub dostatku kraju, ale o ich charakterze rozstrzygają polityka i instytucje polityczne" (s. 56).

Na poziomie konkretu instytucje wyłączające cechuje więc podporządkowanie gospodarki polityce oraz oparcie tej drugiej na podstawach przemocy i arbitralnej decyzji władcy lub władców. Z kolei instytucje włączające w polityce obejmują to wszystko, co utożsamiamy z demokracją we współczesnym jej rozumieniu: rządy prawa, podstawowe wolności obywatelskie oraz wybieralny parlament. Swe ostateczne zwycięstwo w Europie Zachodniej instytucje włączające zawdzięczają instytucjonalizacji w dziedzinie polityki pluralizmu, który z kolei uczynił możliwym rozwój gospodarki rynkowej. Istotą cechy włączania w obu obszarach, polityki i ekonomii, jest konkurencja rządzona przez względnie skutecznie egzekwowane, uniwersalne, obiektywne reguły. Tak wygląda $\mathrm{w}$ ogólnym zarysie model teoretyczny służący autorom do wyjaśnienia wybranych, obejmujących wszystkie kontynenty i kultury, przypadków.

*

Acemoglu i Robinson przeciwstawili ten model stanowiskom teoretycznym, w których kładzie się nacisk na geografię i klimat, kulturę lub ignorancję przywódców politycznych. Wśród przedstawicieli stanowiska geograficzno-klimatycznego wymieniają Monteskiusza, co jest zasadne, choć w jego dziele jest to temat marginalny, oraz Jareda Diamonda (2010). Stwierdzaja przy tym kategorycznie, iż „[...] nierówności na świecie nie sposób wyjaśnić klimatem, chorobami czy jakąkolwiek inną odmianą hipotezy geograficznej" (s. 64).

Równie dobrze mogliby polemizować $\mathrm{z}$ własnym stanowiskiem przedstawionym ponad dziesięć lat wcześniej (Acemoglu, Johnson, Robinson 2001). Uważali wówczas, iż polityka stosowana przez kolonizatorów na obszarach podbitych różniła się $\mathrm{W}$ zależności od klimatu, który rozstrzygał o typie powstających tam instytucji. Na terenach zasobnych w bogactwa naturalne, lecz 
o nieprzychylnym dla europejskich osadników klimacie powstały instytucje wyłączające ${ }^{12}$. Ich przeciwieństwem były sprzyjające zasiedleniu obszary o klimacie umiarkowanym, gdzie imigranci $z$ naszego kontynentu odtwarzali europejskie wzory instytucjonalne, z naciskiem na własność prywatną i demokratyczną kontrolę nad rządem. Na podstawie bogatego materiału historycznego autorzy ci dowodzili, iż o tym, która możliwość była zrealizowana, decydowały przede wszystkim wpływające na śmiertelność kolonistów warunki klimatyczne: gdy śmiertelność była wysoka tworzono „instytucje wyzyskujące”, w warunkach sprzyjających osadnictwu — powstały instytucje chroniące prawa własności i zapewniające demokratyczną kontrolę nad sprawowaniem rządów. Wczesne warunki towarzyszące kolonizacji stworzyły „zależność od szlaku”, której nie zdołała zmienić dekolonizacja (Acemoglu, Johnson, Robinson 2001, s. 1370).

Interesujące, że w swej ostatniej książce Acemoglu i Robinson nie tylko nie odnoszą się do wcześniejszych poglądów, ale pomijają też prace wybitnego historyka gospodarczego, kolegi Robinsona z Uniwersytetu Harvarda, Davida Landesa. Landes (2000, s. 24-49) przekonująco uzasadnił tezę o wpływie geografii i klimatu na rozwój polityczno-gospodarczy. Klimat i geografia wszystkiego nie wyjaśni, lecz trudno całkiem negować, jak to robią omawiani autorzy, wpływ tego czynnika na rozwój polityczno-gospodarczy ${ }^{13}$. Żaden pojedynczy czynnik wszystkiego nie wyjaśni - ewentualnie poza Opatrznością, ale ta jest empirycznie nieweryfikowalna.

Innym podejściem kwestionowanym przez tych autorów jest „hipoteza kulturowa”. Jej źródło lokują w studium Maksa Webera o protestantyzmie i duchu kapitalizmu. Dalece wszakże uprościli stanowisko Webera, który analizy zawarte $\mathrm{w}$ tym eseju opatrzył szeregiem zastrzeżeń metodologicznych, a kwestii różnorakich uwarunkowań rozwoju cywilizacyjnego poświęcił dzieło życia (Weber 2002).

Poglądy Acemoglu i Robinsona na rolę czynnika kulturowego budzą poważniejsze wątpliwości niż tylko upraszczająca interpretacja tez Webera. Jak na podstawie badań nad włoską administracją regionalną wykazał inny kolega Robinsona z Uniwersytetu Harvarda, Robert Putnam: w ramach tego samego systemu ustrojowego identyczne instytucje państwowe różnią się zasadniczo pod względem sprawności i skuteczności działań. Putnam wyjaśnił te różnice odwołując się do odmiennych tradycji kulturowych. Południe Włoch, zdominowane do końca XVIII wieku przez rządy monarchii absolutnej, nie było w stanie także pod koniec wieku XX stworzyć dobrze działających instytucji samorządo-

12 Dotyczyło to nie tylko surowców mineralnych, ale także kauczuku, trzciny cukrowej, guano itp.

13 Nie są tu zresztą konsekwentni. W paragrafie wprowadzającym do podrozdziału „Długie lato” (s. 158-159) odnotowują, iż ok. roku 9600 p.n.e. spadek temperatur na kuli ziemskiej, w ciągu dziesięciu lat o siedem stopni Celsjusza, stanowił punkt zwrotny (critical juncture) w przejściu ludzkości do życia osiadłego. 
wych. Zdecydowanie inaczej eksperyment samorządowy wypadł w północnych Włoszech, gdzie przetrwały tradycje republikańskie (Putnam 1995).

Nie bez kozery więc przywołany wcześniej David Landes (2000, s. 577) z emfazą stwierdza: ,jeśli historia rozwoju czegoś nas uczy, to tego, że o wszystkim przesądza kultura". Landes przwiązuje w swych analizach szczególną wagę do roli kobiety w rodzinie i w społeczeństwie oraz do kulturowo uwarunkowanego podejścia do czasu jako do czynników sprzyjających lub hamujących rozwój gospodarki. Tym między innymi wyjaśnia, dlaczego w Chinach kapitalizm nie rozwinął się wcześniej niż w Europie, a także zacofanie arabskiego kręgu kulturowego. Na znaczenie kultury w wyjaśnianiu zjawisk gospodarczych zwracają uwagę niemal wszyscy badacze procesów rozwojowych. Nie zmienia to faktu, iż niekiedy wyjaśnienia zjawisk w kategoriach kultury mogą przybrać formę karykaturalną. Jednak nieumiejętność użycia nie dyskredytuje narzędzia.

Sądzimy, iż źródłem nieporozumienia co do roli kultury w rozwoju polityczno-gospodarczym jest ujęcie kwestii instytucji. Pojęcia tego Acemoglu i Robinson nigdzie nie definiują. Skoro jednak odniesiemy je, jak to się zwykle czyni, do obowiązujących norm i reguł działania, to automatycznie zostają powiązane $z$ wzorami zachowań, normami i wartościami, a tym samym z całym obszarem kultury społeczeństwa. Instytucje są integralną częścią kultury, a zmiana instytucji jest jednocześnie zmianą kultury społeczeństwa. Już Hobbes oraz Monteskiusz mieli pełną świadomość, że zmieniając instytucje zmieniamy też kulturę.

Na przykład stworzenie nowoczesnej administracji wymagało usunięcia barier stanowych, religijnych i etnicznych oraz uniwersalizacji wartości. Jak zaś dowodził Weber (2002), promotorem tej zmiany była właśnie biurokracja. Ale po to, by mogła się ona pojawić, potrzebna była centralizacja władzy, do czego Acemoglu i Robinson przywiązują istotne znaczenie, oraz nacisk na sprawność w pozyskiwaniu środków na prowadzenie wojen — czym się nie zajmują. Wszystko to razem oznacza daleko idące zmiany w sferze kultury, rozumianej zarówno jako czynnik sprawczy innych zmian, jak i ich efekt. Od uczonych tej klasy należałoby wymagać większej dyscypliny metodologicznej.

Autorzy stosują do swojego modelu określenie „nasza teoria”. Skłania to nas do postawienia dwu pytań: Po pierwsze, w jakim stopniu jest to „ich” teoria, a w jakim rekapitulacja tradycyjnie rozumianego, standardowego podejścia liberalnego? Po drugie, jaki jest teoretyczny status analiz Acemoglu i Robinsona, to jest jak definiują i operacjonalizują oni stosowane przez siebie pojęcia, jak weryfikują swoje hipotezy?

Odpowiedź na pierwsze pytanie brzmi: na poziomie teorii, o ile pominąć typologizację, a właściwie głównie nazwanie, instytucji jako „wyłączających” i „włączających”, wszystko pozostałe jest względnie standardową kontynuacją 
tradycji dziewiętnastowiecznego liberalizmu ${ }^{14}$. Dzieło Adama Smitha Badania nad natura i przyczynami bogactwa narodów jest prowadzoną z pozycji gospodarki rynkowej, a więc z pozycji liberalnych, polemiką z teoriami ekonomicznymi merkantylizmu, które służyły uzasadnieniu monarchii absolutnej. Smith propagował więc instytucje włączające. Podobnie dzieła Alexisa de Tocqueville'a, Demokracja w Ameryce oraz Dawny ustrój $i$ rewolucja, zawierają przeciwstawienie charakterystycznych dla Ameryki instytucji włączających opanowanemu przez instytucje wyłączające ustrojowi Francji. John Stuart Mill znakomicie opisał ograniczenia, jakie zróżnicowania stanowe i związane z nimi beneficja stwarzały dla rozwoju polityczno-gospodarczego. Skłoniło go to, by zdecydowanie wystąpić na rzecz otwarcia instytucji politycznych i gospodarczych na konkurencję, to jest na rzecz włączania. Badania nad związkami między innowacyjnością, strukturą organizacji i charakterem otoczenia, prowadzone w latach sześćdziesiątych XX wieku (Burns, Stalker 1961; Lawrence, Lorsch 1967), znakomicie opisują znaczenie struktur otwartych na innowacje.

W pierwszej połowie XX wieku Joseph Schumpeter (2009, s. 99-106) wprowadził do analizy rozwoju gospodarki pojęcie „twórcza destrukcja”, które Acemoglu i Robinson przejęli, nie wzbogacając go jednak o nowe treści. Karl Wittfogel (1956), a z innych pozycji Friedrich von Hayek (2006) czy Ludvig von Mises (2008) przedstawili dogłębne analizy stwarzanych przez instytucje wyłączające ograniczeń rozwojowych. Myślenie w kategoriach włączania/wyłączania istniało na długo przedtem, zanim tak zostało nazwane.

Wspomniane studia porównawcze socjologów, politologów, historyków prawa i gospodarki, inspirowanych dorobkiem Maksa Webera: Barringtona Moore'a jr. (1966), Samuela Huntingtona (1968), Douglasa C. Northa (1981, 1990) i innych, zawierają analizy często przewyższające pod względem teoretycznym i metodologicznym pracę Acemoglu i Robinsona. Omawiani autorzy zatem, wbrew zawartym w książce i w niektórych recenzjach sugestiom, znajdują się w licznym i dobranym towarzystwie. Trudno więc przyjąć opinię o całkowitym nowatorstwie ich przedsięwzięcia.

Powyższe uwagi krytyczne nie zmieniają naszej wysokiej oceny omawianej pracy. Uważamy tylko, że określenie „nasza teoria”, ignorowanie ważnych prac innych uczonych oraz informacja na okładce, że "od czasu Bogactwa narodów Adama Smitha nie było tak kompleksowej analizy rozkwitu i upadku narodów”, znacznie wyolbrzymiają rzeczywisty wkład autorów do wiedzy o rozwoju polityczno-gospodarczym. Wielokrotnie powtarzana teza, że narody przegrywają

\footnotetext{
${ }^{14}$ Nawet w tym przypadku jednak pojęciowo bliska temu rozróżnieniu jest stosowana przez Henryka Szlajfera (2012) dystynkcja między nacjonalizmem holistycznym i partykularystycznym lub użyte przez Mancura Olsona (2012, s. 49-57) rozróżnienie między grupami ekskluzywnymi i inkluzyjnymi czy podobne rozróżnienie tegoż autora między special-interest and encompassing organizations (Olson 1982, s. 47-53, 90-92). Bliską temu problematyką zajmował się też James M. Buchanan (1965).
} 
z powodu instytucji wyłączających, jest do przyjęcia, z pewnymi zastrzeżeniami, lecz po sprecyzowaniu sensu pojęć okazuje się dość oczywista.

Zastrzeżenia budzi sposób prezentacji tego, co autorzy określają mianem „teorii”. W opisie stosowanych pojęć przeważają ogólniki. Brak jest próby ich zdefiniowania czy nawet zadowalającej operacjonalizacji zmiennych dla celów empirycznej weryfikacji twierdzeń. W związku z tym zawarty w pracy materiał empiryczny można traktować wyłącznie jako ilustrację tez, a nie jako podstawę dowodową. Między ogólnie sformułowanymi hipotezami a szczegółowym opisem przypadków historycznych często nie ma jasno określonego związku, czyli brak jest, by użyć terminologii Roberta Mertona, teorii średniego zasięgu, która łączyłaby analizę przypadków z poziomem teorii ogólnej.

Przyjrzyjmy się na przykład sposobowi, w jaki autorzy traktują podstawowe pojęcia stosowane w pracy, to jest „instytucje wyłączające” oraz „instytucje włączające”, a także kluczowy dla ich analizy zmian termin „punkty zwrotne”. Jakkolwiek rozumiane „włączenie” lub „wyłączenie” dotyczy granic instytucji: instytucje bez granic nie istnieją. Wszystkie zatem muszą wyłączać pewne elementy otoczenia i włączać inne. Istota rzeczy dotyczy reguł rządzących włączaniem lub wyłączaniem. Instytucje „włączające” bazują na regułach uniwersalnych, gdy „wyłączające” rządzą się regułami partykularystycznymi. Pozwala to też przypisać tym drugim charakter wyzyskujący. Po przyjęciu takiego wyjaśnienia całość wywodu Acemoglu i Robinsona staje się przekonująca.

Co do problemu „punktów zwrotnych”, stwierdziwszy synergię między instytucjami gospodarczymi i politycznymi, Acemoglu i Robinson piszą:

„Wyzyskujące instytucje polityczne koncentrują władzę w rękach nielicznej elity, a na jej wykorzystanie nakładają niewielkie ograniczenia. Potem owa elita bardzo często tak kształtuje instytucje gospodarcze, aby eksploatować zasoby reszty społeczeństwa. Tak więc wyzyskujące instytucje gospodarcze w naturalny sposób towarzyszą wyzyskującym instytucjom politycznym, a nawet więcej - mogą trwać dzięki spleceniu z tymi ostatnimi. Z kolei włączające instytucje polityczne, ponieważ upowszechniają władzę, będą skłaniać raczej do obalenia instytucji gospodarczych, które umożliwiają odbieranie zasobów wielu ludziom, wznoszą bariery wejścia i ograniczają funkcjonowanie rynków, aby korzystała z nich niewielka garstka ludności" (s. 97).

Brak precyzyjnego określenia pojęć powoduje, że trudno je odnieść do pokrewnych, wcześniej wspomnianych rozróżnień (Olson 2012; Buchanan 1965; Szlajfer 2012). Ponadto jeśli przyjmujemy, że siła instytucji zależy od skuteczności utrzymywania granic, a zatem również od kontroli wejść, to przydatne dla teorii byłoby wyjaśnienie różnic między proponowanymi przez Acemoglu i Robinsona typami instytucji pod względem sposobu realizacji przez nie tej funkcji.

Centralizacja władzy i ustanowienie jednolitego systemu prawa jest, według tej koncepcji, warunkiem koniecznym, ale niewystarczającym rozwoju. Koncentracja władzy w instytucjach kontrolowanych przez niewielką grupę lu- 
dzi prowadzi do ich petryfikacji, eliminując niezbędny dla rozwoju mechanizm „twórczej destrukcji” (s. 173). Tylko „włączająca” instytucjonalizacja szerokiego uczestnictwa w sprawowaniu rządów (policentryczność), konkurencja, umożliwia przezwyciężenie barier rozwojowych. Instytucje włączające „umożliwiają swobodną działalność niezależnym mediom" (s. 362). Autorzy zachowują jednak ostrożność. W innym miejscu bowiem piszą: „[...] nawet jeśli demokracja nie jest tym samym co włączające instytucje, to jednak regularne wybory i względnie swobodna rywalizacja polityczna prawdopodobnie spowodują rozwój tych instytucji" (s. 492). Demokracja jest więc warunkiem koniecznym, ale nie wystarczającym włączania. Wynikiem działania instytucji wyłączających jest brak praw własności, praworządności i porządku, źle funkcjonujące sądownictwo i paraliżująca dominacja elit (s. 502). „Kamieniem węgielnym" instytucji włączających jest pluralizm (s. 509). Instytucje włączające wiążą się $z$ wolnością, prawem własności i skutecznym egzekwowaniem kontraktów. Jest to ogólnie rzecz biorąc słuszne, lecz nie ma w tym nic oryginalnego. Wielokrotnie wykazywano już bowiem, że instytucje gospodarcze (takie jak prawa własności, instytucje regulacyjne, instytucje służące stabilizacji makroekonomicznej czy rozwiązywaniu konfliktu, ubezpieczenia społeczne itp.) są istotnym źródłem wzrostu gospodarczego (np. North 1981; Rodrik 2007). Decydują one o inwestycjach w kapitał fizyczny i ludzki, w nowe technologie i produkcję przemysłową. Dawno też zrozumiano, iż — obok krytycznej roli w generowaniu wzrostu gospodarczego - instytucje ekonomiczne wpływają znacząco na dystrybuję zasobów.

Jak wskazują powyższe cytaty, autorzy opisują swoje typy instytucji luźno wiążąc je $z$ efektami ich działania, a nie ze sposobem, $w$ jaki je osiągają ${ }^{15}$. Ich „teoria” zyskałaby na precyzji i rygorze, gdyby spróbowali zdefiniować stosowane narzędzia pojęciowe, chociażby w kategoriach typów idealnych Webera. Jeżeli przyjąć, że instytucje wyłączające w skrajnej postaci mają formę ustroju totalitarnego, to przecież ustrój taki jest dobrze opisany w literaturze naukowej; podobnie jak ustrój polityczny, który gdy uznamy go za poliarchię, to jest włączający typ instytucji politycznych, musi spełnić warunki proponowane przez Roberta Dahla (1974, s. 221).

Ostrożność w zaliczaniu wszystkich ustrojów demokratycznych do kategorii jednoznacznie włączających ma pewne uzasadnienie. Zdarzają się też takie, które spełniając warunki Dahla, są jednak tak skonstruowane, że wyłączają znaczące środowiska społeczne $z$ udziału w procesach polityczno-gospodarczych ${ }^{16}$.

\footnotetext{
${ }^{15} \mathrm{Na}$ przykład instytucje włączające „bronią praw własności”, „tworzą pole gry z regułami jednakowymi dla uczestników”, „zachęcają do inwestowania w nowe technologie i umiejętności” itp. (s. 477).

16 Taką interpretację rozwiązań ustrojowych pokomunistycznej Polski zawiera praca współautora tej recenzji (Kamiński 2014); w odniesieniu do polityki gospodarczej rządu Stanów Zjednoczonych podobne tendencje opisali James Bessen (2015) oraz John Chambers i Myron Ullman (2015).
} 
Jak wspomnieliśmy, w ustroju zaprojektowanym jako włączający mogą rozwinąć się, na skutek niewłaściwych polityk i koalicji interesów, instytucje o charakterze wyłączającym (Phelps 2013; Bessen 2015; Chambers, Ullman 2015). Może też być odwrotnie: w ustroju totalitarnym, w trakcie jego ewolucji, mogą rozwinąć się, w pewnych granicach, elementy włączania, czego przykładem są Chiny po Mao Tse-tungu. W obu przypadkach nadmierne odchylenia od założonej w projekcie logiki ustroju grożą destabilizacją polityczną, chociaż jej skutki będą się różnić, tak jak różnią się same logiki tych porządków.

Pojęcie punktu zwrotnego pojawia się za każdym razem, gdy ustrój polityczno-gospodarczy przechodzi zmianę w kierunku „włączania” lub „wyłączania". Acemoglu i Robinson w następujący sposób charakteryzują taki proces:

„Zasadnicze zmiany instytucjonalne, istotne dla poważnych zmian gospodarczych, zachodzą $\mathrm{w}$ rezultacie interakcji pomiędzy istniejącymi instytucjami a punktami zwrotnymi. Owe punkty to znaczące wydarzenia, które zakłócają istniejącą równowagę polityczną i gospodarczą w jednej lub kilku społecznościach; przykładami punktów zwrotnych były czarna śmierć, która w czternastym wieku w niektórych regionach Europy uśmierciła być może aż połowę ludności, otwarcie szlaków morskich wykorzystywanych dla handlu transatlantyckiego, co licznym narodom zachodnioeuropejskim stworzyło możliwość wielkich zysków, czy rewolucja przemysłowa, która generowała szybkie, ale też wstrząsowe zmiany struktur gospodarczych w świecie" (s. 478).

Rozpoznajemy punkt zwrotny dzięki temu, że dokonała się obserwowalna zmiana instytucjonalna. Pojęcie to nie rozświetla więc nam zjawiska zmian instytucjonalnych jako takiego - pozwala tylko skonstatować ich wystąpienie. Rozwiązaniem tego problemu jest przyjęcie, że punkty zwrotne pojawiają się wtedy, kiedy zmiany w otoczeniu systemu polityczno-gospodarczego napotykają odpowiedni stan instytucji, który umożliwia „dostrzeżenie” i wykorzystanie nowych możliwości. Punkty zwrotne stają się takimi dzięki zdolności instytucji do adaptacyjnego zareagowania na nowe warunki w otoczeniu, a nie wskutek samych zmian w otoczeniu. Autorzy piszą o epidemii, która w XIV wieku nawiedziła Europę, jako o czynniku, który spowodował zwrot $\mathrm{w}$ rozwoju instytucjonalnym, ale epidemie wielokrotnie występowały w historii rozwoju ludzkości nie przynosząc podobnych efektów. Podobnie fakt, że Chińczycy na długo przed Europejczykami podejmowali eksploracje morskie, nie wywołał tam takich skutków, jakie miał w Europie. Możliwości techniczne oraz innego rodzaju „okazje”, aby miały efekt rozwojowy, muszą trafić na właściwe warunki instytucjonalne.

Autorzy rozpatrują sukces czy porażkę w kategoriach rozwoju instytucji narodowych. Państwa jednak funkcjonują w przestrzeniach określonych przez układy międzynarodowe, które globalizacja niesłychanie uaktywniła. Przystąpienie do Unii Europejskiej wymaga na przykład przyjęcia acquis communautaire, co w dużej mierze zmienia architekturę instytucjonalną systemu gospodarczego. Czy polityki promowane z Brukseli pobudzają do rozszerzenia instytucji 
i polityk włączających czy wyłączających? Pytanie to można odnieść do innych porozumień regionalnych lub multilateralnych. W jaki sposób hegemoni regionalni wpływają na sukces lub przegraną poszczególnych krajów? Jaki mają wpływ na ewolucję instytucjonalną?

Można na koniec zadać pytanie, dlaczego książka, która ma tak wiele braków, została tak entuzjastycznie przyjęta przez rynek czytelniczy? Dlaczego autorzy tej recenzji także są skłonni gorąco zalecić jej lekturę nie tylko ekonomistom, socjologom, ale także politykom gospodarczym i tzw. oświeconej publiczności, jeśli pojęcie to ma jeszcze sens? Odpowiedź na te pytania jest prosta: Acemoglu i Robinson postawili właściwe problemy we właściwym czasie oraz podjęli próbę ich rozwiązania, wskazując właściwy kierunek.

Współczesna cywilizacja rozwinęła się, na dobre i na złe, dzięki powstaniu instytucji, które skutecznie ograniczyły arbitralność władzy politycznej. Stało się to możliwe dzięki uzupełnieniu, opartych na przymusie, hierarchicznych form kontroli przez mechanizmy kontroli oddolnej oraz poziomej, które łącznie zapewniły otwartość dostępu do systemu polityczno-gospodarczego oraz rozliczalność władzy. $Z$ tego punktu widzenia logika organizacji gospodarki rynkowej jest zbieżna $z$ logiką demokracji. W obu przypadkach konkurencja pełni ważne funkcje regulacyjne. Zatem opinia, że model reprezentowany przez ChRL może być alternatywą dla cywilizacji Zachodu, jest pozbawiona racjonalnych przesłanek.

Kluczem do zrozumienia sukcesów państw na polu polityczno-gospodarczym jest sprawność w rozwiązaniu problemu wykorzystania potencjału, jaki stwarza rosnący społeczny podział pracy — to jest problemu kontroli i koordynacji. W ostatecznym rozrachunku tylko ekonomiczne instytucje włączające mogą uruchomić czynniki długookresowego wzrostu gospodarczego; i tylko polityczne instytucje włączające mogą w dłuższym horyzoncie czasu zapewnić jego trwałość. Chiny zdobyły sukces dzięki uwolnieniu rezerw tkwiących $\mathrm{w}$ gospodarce oraz uruchomieniu potencjału ludzkiego poprzez ogromne inwestycje w kapitał fizyczny i ludzki, ale ich ustrój polityczny stanowi czynnik ograniczający zdolność racjonalnego wykorzystania tych zasobów. Powoduje to, że „Wzrost taki jest z konieczności ograniczony i nietrwały”. Słusznie Acemoglu i Robinson kwestionują opinię, że przyjęta przez Chiny strategia wzrostu gospodarczego stanowi „wartościową alternatywę dla konsensusu waszyngtońskiego" ${ }^{17}$. Ta strategia wzrostu jest atrakcyjna „przede wszystkim dla tych, którzy obecnie kierują instytucjami wyzyskującymi, a zdobywają w ten sposób argumenty za trwaniem przy władzy, a nawet zwiększaniem jej zakresu

$17 \mathrm{~W}$ polskiej literaturze takie stanowisko reprezentuje, jak się wydaje, Krzysztof Jasiecki (2013, s. $26-42)$. 
i umacnianiem wyzysku" (s. 489-490). Z tych względów Acemoglu i Robinson uważają, iż w przewidywalnym czasie, $z$ powodu niezgodności między częściowo włączającym charakterem instytucji gospodarczych a wyłączającymi instytucjami politycznymi, Chiny staną wobec nieprzezwyciężalnej bariery rozwoju gospodarczego i groźby stagnacji.

Współczesna cywilizacja ludzka, co obecnie odnosi się do instytucji stworzonych $\mathrm{w}$ ramach szeroko pojętego Zachodu, jest wrażliwa zarówno na zagrożenia zewnętrzne, czego dobitnym przykładem są ekspansywne ambicje Rosji i Chin, jak i - w nie mniejszym stopniu - na zagrożenia wewnętrzne o charakterze przede wszystkim kulturowym (Bell 2014; Wildavsky 1991). Upadek tej cywilizacji jest całkiem prawdopodobny, a musiałaby towarzyszyć mu niewyobrażalna katastrofa humanitarna. Wielką zasługą autorów jest, że w sposób dobitny pokazali, iż utrzymanie procesów rozwoju polityczno-gospodarczego wymaga wprowadzenia i utrzymania na poziomie państw otwartych rozwiązań instytucjonalnych oraz realizacji chroniących je polityk.

\section{BIBLIOGRAFIA}

Acemoglu Daron, Robinson James A., 2014, Dlaczego narody przegrywają: źródła władzy, pomyślności i ubóstwa, tłum. Jerzy Łoziński, Zysk i Ska, Poznań.

Acemoglu Daron, Johnson Simon, Robinson James A., 2001, The Colonial Origins of Comparative Development: Empirical Investigation, „The American Economic Review”, t. 91, s. 1369-1401.

Bell Daniel, 2014 [1996], Kulturowe sprzeczności kapitalizmu, tłum. Stefan Amsterdamski, Aletheia, Warszawa.

Berman Harold, 1995 [1986], Prawo i rewolucja. Ksztattowanie się zachodniej tradycji prawnej, tłum. Stefan Amsterdamski, Wydawnictwo Naukowe PWN, Warszawa.

Bessen James, 2015, The Anti-Innovators, „Foreign Affairs”, t. 94, s. 55-60.

Bremmer Ian, 2006, The J Curve: A New Way to Understand Why Nations Rise and Fall, Simon \& Schuster, New York.

[BS] Bank Światowy, 1993, The East Asian Miracle: Economic Growth and Public Policy. A World Bank Policy Research Report published by the Oxford University Press, Washington DC.

Buchanan James, 1965, An Economic Theory of Clubs, „Economica”, t. 32, s. 1-14.

Burns Tom, Stalker G. M., 1961, The Management of Innovation, Tavistock, London.

Chambers John, Ullman Myron E., 2015, Stopping the Economy - Sapping Patent Trolls, „The Wall Street Journal", 17 lutego (A9).

Cipolla Carlo M., 1970, Introduction, w: Carlo M. Cipolla (red.), The Economic Decline of Empires, Methuen, London.

Collier Paul, 2007, The Bottom Billion: Why the Poorest Countries Are Failing and What Can Be Done About It, Oxford University Press, Oxford-New York.

Dahl Robert, 1974, Polyarchy: Participation and Opposition, Yale University Press, New Haven.

Diamond Jared, 2010, Strzelby, zarazki, maszyny: losy ludzkich spoteczeństw, tłum. Marek Konarzewski, Prószyński Media, Warszawa.

Hayek Friedrich August von, 2006 [1960], Konstytucja wolności, tłum. Janusz Stawiński, Wydawnictwo Naukowe PWN, Warszawa. 
Huntington Samuel P., 1968, Political Order in Changing Societies, Yale University Press, New Haven-London.

Jasiecki Krzysztof, 2013, Kapitalizm po polsku: między modernizacja a peryferiami, Wydawnictwo IFiS PAN, Warszawa.

Kamiński Antoni Z., 2014, Dezercja elit. Konsolidacja ustroju politycznego w pokomunistycznej Polsce, ISP PAN, Warszawa.

Kamiński Antoni Z., Kamiński Bartłomiej, 2004, Korupcja rządów. Państwa pokomunistyczne wobec globalizacji, Trio-ISP PAN, Warszawa.

Kindleberger Charles P., 1996, World Economic Primacy 1500-1990, Oxford University Press, New York-Oxford.

[KW] Commission for Growth and Development, 2008, The Growth Report: Strategies for Sustained Growth and Inclusive Development, International Bank for Reconstruction and Development, Washington DC.

Landes David S., 2000, Bogactwo i nędza narodów. Dlaczego jedni sa tak bogaci, a inni tak ubodzy, tłum. Hanna Jankowska, Muza, Warszawa.

Lawrence Paul R., Lorsch Jay W., 1967, Organization and Environment, Harvard Business School, Boston, MA.

Mises Ludvig, von, 2008, The Anti-Capitalistic Mentality, The Ludwig von Mises Institute, Auburn, Alabama.

Moore Barrington Jr., 1966, Social Origins of Dictatorship and Democracy: Lord and Peasant in the Making of Modern World, Penguin, London.

North Douglass C., 1981, Structure and Change in Economic History, W.W. Norton, New York-London.

North Douglass C., 1990, Institutions, Institutional Change, and Economic Performance, Cambridge University Press, Cambridge.

Olson Mancur, 1982, The Rise and Decline of Nations: Economic Growth, Stagflation, and Social Rigidities, Yale University Press, New Haven-London.

Olson Mancur, 2012 [1965], Logika działania zbiorowego: dobra publiczne i teoria grup, tłum. Sebastian Szymański, Scholar, Warszawa.

Phelps Edmund, 2013, Mass Flourishing: How Grassroots Innovation Created Jobs, Challenge and Change, Princeton University Press, Princeton NJ.

Putnam Robert D., 1995, Demokracja w działaniu. Tradycje obywatelskie we wspótczesnych Wtoszech, tłum. Jakub Szacki, Znak-Fundacja im. Stefana Batorego, Kraków-Warszawa.

Rodrik Dani, 2007, One Economics Many Recipes: Globalization, Institutions, and Economic Growth, Princeton University Press, Princeton.

Schumpeter Joseph A., 2009 [1942], Kapitalizm, socjalizm, demokracja, tłum. Michał Rusiński, Wydawnictwo Naukowe PWN, Warszawa.

Skocpol Theda, 1979, States and Social Revolutions: A Comparative Analysis of France Russia and China, Cambridge University Press, Cambridge, Mass.

Szlajfer Henryk, 2012, Economic Nationalism and Globalization: Lessons from Latin America and Central Europe, Brill, Leiden-Boston.

Teulings Coen, Baldwin Richard (red.), 2014, Secular Stagnation: Facts, Causes and Cures, CEPR Press, London.

Tilly Charles, 1990, Coercion, Capital and European States, AD 990-1990, Blackwell, Cambridge, Mass.

Tilly Charles, 1997 [1993], Rewolucje europejskie, 1492-1992, tłum. Elżbieta Żelazna, Krąg-Volumen, Warszawa.

Wallerstein Immanuel, 1974, The Modern World System, Academic Press, New York.

Weber Max, 2002, Gospodarka i spoteczeństwo. Zarys socjologii rozumiejacej, tłum. Dorota Lachowska, Wydawnictwo Naukowe PWN, Warszawa. 
Wildavsky Aaron, 1991, The Rise of Radical Egalitarianism, The American University Press, Washington.

Wittfogel Karl, 1956, Oriental Despotism, Yale University Press, New Haven.

\section{THE DRIVING FORCES OF SOCIO-ECONOMIC DEVELOPMENT: REFLECTIONS IN THE CONTEXT OF ACEMOGLU AND ROBINSON'S CONCEPTION}

\section{Summary}

This paper critically assesses Acemoglu and Robinson's framework for examining economic development. The framework is applied to cases taken from a period of more than two thousand years, yet it-and consequently its implementation-suffer from serious methodological flaws. First, the authors fail to define their basic concepts and terms precisely. Their choice of critical junctures generating breakthroughs is similarly limited to those that produced changes but ignores others that did not. Furthermore, their major claim that institutions are the only determinant of prosperity does not withstand scrutiny. Other factors, including the much-criticized ones of culture and geography, may be shown to be more critical under some circumstances. Last but not least, their failure to establish links between their framework and the literature on democracy and capitalism is rather striking. Juxtaposing their analysis and this literature could generate new insights. Nevertheless, this is not to suggest that their framework is 'old wine in new bottles'. To the contrary, their analysis will undoubtedly stimulate further research into the complexity of relations between political and economic institutions and their impact on social and economic development.

\section{Key words/słowa kluczowe}

Daron Acemoglu and James A. Robinson / Daron Acemoglu i James A. Robinson; factors in socio-economic development / czynniki rozwoju społeczno-gospodarczego; politics and economics / polityka a gospodarka; crisis of the Western world / kryzys świata zachodniego 